\title{
Study on the Development Mode of Red Cultural Heritage in Qingyang
}

\author{
Fei Wang ${ }^{1}$, Jinghua Zhang ${ }^{2}$ \\ ${ }^{1}$ College of History and Geography, Longdong University, Qingyang, Gansu, 745000, P.R. China \\ ${ }^{2}$ College of Economics and Management, Longdong University, Qingyang, Gansu, 745000, P. R. China
}

Keywords: Qingyang, red cultural heritage, development model

\begin{abstract}
The paper, through the integration of cultural heritage and red tourism resources concept, defines the meaning of red cultural heritage. By combing the general pattern of red cultural heritage and development, it puts forward a mode of Qingyang red cultural heritage, that Qingyang must standing on the strategic height to develop the red cultural tourism and points out that the route selection of Qingyang red cultural heritage development.
\end{abstract}

\section{Introduction}

As an important part of the historical and cultural heritage of our country, the red cultural heritage contains the unique spiritual value and thinking mode of the Chinese nation , bears the great revolutionary spirit, embodies the national will of the nation of the Chinese nation , becomes an important red cultural resource of building a well - off society in a comprehensive way , and plays an important role in promoting the social progress , economic development and national unity of our country.

\section{The Concept of Red Cultural Heritage}

In 2004, Chinese Communist Party Central Office and General Office of State Council jointly implemented the definition of "Red Tourism "in the Outline of the National Red Tourism Development Plan 2004-2010, which was jointly implemented by the General Office of the State Council. According to the definition of the Outline of the CPC, the red cultural tourism resources should be "the important revolutionary memorial halls, memorials, memorials and the revolutionary spirit carried by the Central Revolutionary Base Area, Red Army Long March, Anti-Japanese War and War of Liberation."

Red Cultural Heritage was put forward in the five - year plan for the development of red tourism. The plan pointed out that the relevant protection system of "Red Cultural Heritage " should be intensified as soon as possible, but no clear definition of the red cultural heritage was made.

Cultural heritage is divided into intangible cultural heritage and material cultural heritage. Material cultural heritage includes architectural complex, cultural relics and ruins. It has history. The intangible cultural heritage includes ancient buildings, ancient sites, ancient tombs, stone inscriptions, cave temples, frescoes, modern important historic sites and representative buildings, etc. Non-material cultural heritage is the expression of traditional culture which exists in non-material forms and is closely related to the people's life.

Based on the concept of red tourism resources and cultural heritage, the author thinks the red cultural heritage is Chinese from the founding of the Communist Party of new China established, including the first revolutionary civil war, the second revolutionary civil war, the Anti Japanese War, the liberation war remains, in art, history, sociology and other aspects of the revolutionary Commemorative Building, relics, relics, or mobile literature, physical and literature, arts and crafts etc. The objective existence of the art system of human society, spiritual and cultural products and the bearing reflects the revolutionary spirit, history and stories. 


\section{Red Cultural Heritage Development Mode}

As a special term for research in the field of natural science, "mode" and "model" are often interchangeable. At present, the pattern of development of red cultural heritage in China can be summarized as the following types: red and green combination mode, red ancient binding mode, red performance mode and tourism festival mode.

\subsection{The Development Model of Red and Green Integration}

There is a kind of tourism development mode that red cultural heritage relies on the exploitation of natural green resources. Nearly 250 old revolutionary districts in China are basically located in hills and mountainous areas. With high vegetation coverage, various landforms and other potential tourism resources advantages, some old sites of red culture itself is a scenic spot. For example, Jinggangshan Red Tourism area, which enjoys the reputation of "Cradle of Revolution" and "Green Treasure", is a key scenic spot in China.

\subsection{The Development Mode of Red Culture and Historical Culture}

The mode is to combine the local characteristic historical culture and the red cultural heritage organically, return the development theme of the red cultural heritage to the humanistic spirit of the historical context, truly realize the sustainable development of the local tourism. The revolutionary holy land Yan ' an relies on the Yellow Emperor Ling and the ancient river famous victory kettle mouth waterfall, combines the red cultural heritage and the ancient patriarch cultural relic of the Chinese nation and the Yellow River civilization, is deeply welcomed by the market, and becomes a model of the development of the red culture and the historical culture.

\subsection{The Development Model of the Combination of Red Culture and Folk Culture}

The model refers to the local folk customs and cultural heritage of the red and red combination, do custom dramas. Jiangxi Ruijin, which has a "red hometown", does not have the same quality natural ecology as Jinggangshan, which is also the main reason for the slow development of its green tourism. However, as for the pure Hakka Jiangxi County, Ruijin, Jiangxi, has a rich cultural and cultural atmosphere of Hakka, and the rich and colorful Hakka folk customs attract a large number of tourists from home and abroad.

\subsection{The Development Mode of Red Performance}

The mode is performed with red opera, red ballads, and folk songs and so on. The revolutionary old district left a lot of red songs, drama and other art forms, such as the Red Snake, the Red Army and the Red Army. Typical such as the " Red Cultural Classic " in the Red Army, Liu Sanjie, etc., Shaoshan 's live view shows that Dong Fang Hong Kong is also one of the successful examples.

\subsection{The Development Mode of Tourism Festival}

The model takes the red tourist landscape as the content, the red tourism as the theme, the red culture as the connotation, the red spirit as the attraction point, the tourism festival as the medium, and the red festival as the tourist article. Each revolutionary memorial can use its unique red culture as the theme of the Red Tourism Culture Festival. At present, the tourism cultural festival held in Jinggangshan, Ruijin and Shaoshan, Hunan Province is a perfect combination of "setting up the stage of culture and singing opera in economy".

\section{The Selection of Red Cultural Heritage Development Model in Qingyang}

The sustainable development of Qingyang red cultural tourism resources must adhere to the traditional development model, through regional cooperation, multiple integration, explore a model. Qingyang red cultural tourism core competitiveness lies in the development, mining, integration and protection of rich revolutionary sites, heritage resources and non-material red cultural resources. The author thinks that Qingyang should become a hot area of red cultural tourism; Managers must 
set up a competitive development strategy, which is a kind of tourism development strategy aimed at the homogeneity of tourism resources near the region. This kind of competition is based on cooperation. Under the guidance of this strategy, Qingyang takes the combined development mode when developing the red cultural heritage.

One of the ways of combination development is the combination of red red and red red, that is, the integration of Qingyang red cultural heritage resources and Yan'an red heritage resources, red red teaming up. This model can improve the influence of the whole Shaanxi-Gansu-Ningsia Border region red tourism area, so that the Shaanxi-Gansu-Ningsia Border region red tourism destination really connected into a line. Generally speaking. Homogenization of tourism resources is very easy to lead to homogeneity competition, but if the economic subjects of homogenized tourism resources cooperate with each other, cooperative planning can concentrate the advantages of resources and expand the scale of tourism in red culture. Take the long March of the Red Army as an example, from Jiangxi to Northern Shaanxi, more than 10 provinces, only through cross-regional association, can truly form a red tourism zone. "Red red joint development" is the only way for the development of red tourism. The practice of regional cooperation in the development of red cultural heritage has long had a precedent. April 2004. Shanghai, Beijing, Jiangxi, Fujian, Hebei, Guangdong, Shanxi and other provinces and cities signed the Zhengzhou Declaration opened the red cultural heritage regional cooperation. August 2004. The National Tourism Administration announced the launch of the "Red Tourism" project. On March 2005, 13 departments, including the National Development and Reform Commission, the Central propaganda Department and the National Tourism Administration, jointly issued the notice. Thirty National Red Tour boutique lines and one hundred national Red Tourism classic scenic spots have been announced.

The second combination development mode path is multi - element integration. The development of Qingyang red cultural tourism must seek " red cultural tourism " and " green tourism " , " Loess Plateau folk tourism " , " historical culture and red tourism " etc . Reasonable design week no games "ancestral tomb, zhouzuling Forest Park, the national key cultural relics protection units in North Ziwuling cave temple, Forest Park, Qin straight water section and the national AAA level scenic spots in southern Liang revolutionary memorial hall and other scenic spots, fully integrated into the Qingyang tourism circle. Let visitors feel in the modern revolutionary history Chinese surge high and sweep forward at the same time, also enjoy the Ziwuling rich forest resources and wildlife at the same time, and can enjoy the Chinese agricultural civilization and traditional Buddhist culture spirit connotation, to truly achieve the red culture and long history and beautiful ecological civilization pavilions. Qingyang red culture tourism development in the integration of multiple process should focus on the experience of participating in the development of tourism projects the explanation of the traditional mode of tourism. To enable visitors to understand the history of the red cultural heritage, cultural connotation, reliving the glorious revolutionary history, experience tourism Project development is an effective means to increase the retention time of tourists, and is also an important way to increase the attraction of Qingyang red cultural tourism.

In the process of multi - element integration, the design and development of Qingyang intangible red cultural heritage is also an important measure to promote the development of Qingyang red cultural tourism. The author thinks that the oral inheritance of traditional intangible red cultural heritage should be changed rapidly. Increase the multi-channel transmission of records, such as text records, audio and video records, digital records, etc. On the basis, the creation and official publication of the old district in Qingyang real revolutionary story. The deeds of revolutionary martyrs and revolutionary heroes, revolutionary literature and art should be published and distributed in the form of books, tapes, CDs or DVDs, expand the distribution channels, and make use of the Internet. Set up their own Internet site to promote the Internet, or cooperate with a number of famous, large online bookstores, such as "Amazon Bookstore" "Dangdang Bookstore" and so on. It can also be donated in the form of gifts to large public private libraries at home and abroad. Qingyang Intangible Red Cultural Heritage can also be adapted and produced. Such as Qingyang red classic folk song "our leader Mao Zedong", "embroidered gold plaque", "military and 
civilian production" adaptation, a modern pop song "re-sing our leader Mao Zedong", "the new embroidered gold plaque". These folk songs catered well to the interests of young people and won their love. This also achieved the educational purpose of patriotism education and edification; Also will comment drama "Liu Qiaoer" to carry on the adaptation to carry on the screen and the stage; At the same time, deeply dig the connotation of Qingyang Red Culture, shoot and produce documentary films such as "Soviet Government of Shaanxi-Ganbian District", "Longdong Middle School" and other documentaries broadcast in the central media; Adaptation and production of popular online games, such as the Battle of Castle, will definitely win the majority of teenagers love.

In short, Qingyang red cultural heritage combination development model is based on giving play to the overall advantages of regional red cultural heritage, so that the role of red cultural heritage really integrates into the economic and social development process of Qingyang. To maximize the function and effect of red cultural heritage. Of course, in combination with the development of resources and the local government's positive push and social resources of great pull. The combined development mode of the red cultural heritage in Qingyang old area will make the development of the red cultural heritage of Qingyang reach a new height and rise to a new level.

\section{Acknowledgements}

The paper is the annual strategic research project of colleges and universities in Gansu: the periodical result of the way to improve the overall competitiveness tourism industry under the "One Belt and One Road "strategy in Qingyang (Project No. 2017F - 27).

\section{References}

[1] Documents of the People's Government of Hunan Province. Circular of the People's Government of Hunan Province on the Protection of Cultural Heritage: EB / OL Bldg. 2006 - 09-21. http://www.ir.gov.cn/sy /zk/t2006111113_49161.htm.

[2] Yin Xiaoying. Study on characteristics and development patterns of red tourism products. Human Geography, 2005(2).

[3] Red Tourism Industry in Qingyang Old area is developing vigorously [N]. Gansu Economic Daily, 2012-08-27.

[4] Qingyang tourism "12th Five-Year Plan" prospects [N]. China Travel News 2011-05-11. 